\title{
K materialite v myslení Judith Butlerovej
}

\section{On Materiality in Judith Butler's Thought}

\author{
Jakub Kapičiak
}

\begin{abstract}
Abstrakt
Štúdia sa zameriava na poznámky Judith Butlerovej o chiazmatickom prepojení jazyka a matérie. Ciel'om je zistit', čo takéto prepojenie vôbec znamená a odkial' pramení. Štúdia ukazuje, že ono prepojenie organicky vyplýva z autorkinej koncepcie performatívnej rodovej identity. Autorka prisudzuje telu úlohu aktívneho participanta v procese konštrukcie identity. Tým sa Butlerová vo svojej koncepcii vyhýba kultúrnemu determinizmu a emergencii voluntaristického subjektu. Po stručnom zhrnutí Butlerovej koncepcie performatívnej rodovej identity sa štúdia d'alej zaoberá rozkladom opozície subjektu a objektu v autorkiných prácach. Následne sa už štúdia usiluje vyrovnat's otázkou chiazmatického prepojenia jazyka a matérie.
\end{abstract}

\section{Kl'účové slová}

činitel'ská inštancia - Judith Butlerová - konštruktivizmus - materialita - performativita

\begin{abstract}
The study focuses on Judith Butler's remarks on the chiasmatic interconnection between the language and matter. The aim is to find out, what such an interconnection means and what it emerges from. The study shows that the interconnection is embedded in Butler's conception of the performative gender identity. Posing the body as an active participant of the process of construction of one's identity, Butler tries to avoid cultural determinism and the emergence of a voluntaristic subject. After a brief summary of Butler's conception of a performative gender identity, the study pays attention to the disruption of the opposition between subjects and objects as it appears in Butler's writings. The next part of the paper is dedicated to the issue of the chiasmatic interconnection between language and matter.
\end{abstract}

Štúdia je výstupom projektu Materialita v myšlení Judith Butler realizovaného z prostriedkom Špecifického vysokoškolského výskumu na Filozofickej fakulte Univerzity Karlovej. 


\section{Keywords}

agency - Judith Butler - constructivism - materiality - performativity

\section{Úvod: Materialita ako neuralgický bod konštruktivizmu}

V úvode k druhému vydaniu svojej vplyvnej knihy Gender trouble (Trampoty s rodom) z roku $1999^{1}$ Judith Butlerová sebakriticky poznamenáva, že často tápe medzi lingvistickým a divadelným chápaním performativity. ${ }^{2}$ Dodáva, že väzba medzi týmito dvoma vetvami performativity spočíva v skutočnosti, že „reč ako taká je telesným aktom so špecifickými lingvistickými dôsledkami“ a „[p]reto reč nepatrí ani výlučne do telesnej prezentácie, ani do jazykovej a jej postavenie ako slova a skutku je nevyhnutne dvojznačné“. ${ }^{3} \mathrm{~V}$ eseji venovanej mysleniu de Mana a Descartesa Butlerová v tejto súvislosti vystríha pred rizikom doslovnej interpretácie trópu performativity, ktorej sa dopúštajú autori a autorky, vychádzajúc z predpokladov konštruktivizmu. ${ }^{4}$ Túto doslovnú interpretáciu charakterizuje prístup k materiálnym javom (Butlerovú zaujíma hlavne telo) nielen ako k formovaným jazykom (made by language) na epistemickej úrovni, ale aj ako k sformovaným z jazyka ako z materiálu (made of language). Autorkinou pointou je, že jazyk nemôže uniknút svojej účasti v telesných aktoch. Jazyk a telo sú chiazmaticky prerastené. ${ }^{5}$

$1 \quad$ Kniha prvý raz vyšla v roku 1990.

2 V súčasnom teoretickom diskurze dominuje konštrukcia o dvojakom „pôvode“ performativity. Na jednu stranu sa kladie oblast̉ na priesečníku lingvistiky, analytickej filozofie a dekonštrukcie (od J. L. Austina a J. R. Searla cez J. Derridu, S. Fisha a P. de Mana k J. Butlerovej) a na druhú zasa oblast' interakcií divadelnej teórie a praxe s antropológiou, sociológiou, etnológiou a teóriou a praxou umenia druhej polovice 20. storočia (od avantgardného divadla $\mathrm{k}$ umeniu performancie a od teatrológie k multidisciplinárnym performačným štúdiám). Porovnaj napríklad LOXLEY, J. Performativity a AURELIUS, H. E. - CHENZGHOU, H. - HELGASON, J. Performativity in Literature..., s. 12-16. Problémom tejto konštrukcie môže byt’ aj príliš striktné delenie oblastí a takisto aj nevedomé prechádzanie z jednej do druhej, čo môže vyústit do terminologickej a metodologickej mäteže. V tejto súvislosti vid' MILLER, J. H. Performativity ${ }_{1} /$ performativity $_{2} \ldots$

3 BUTLER, J. Trampoty s rodom..., s. 25.

4 Pod konštruktivizmom mám na mysli chápanie javov ako výsledkov diskurzívneho, kultúrneho či ideologického formovania, a teda ako opozíciu k esencializmu. Vid' MATONOHA, J. a kol. Za (de)konstruktivismem..., s. 242-243. Pre zhrnutie diskusie konštruktivizmus verzus esencializmus v rodových štúdiách vid' KRIŠTOFOVÁ, L. Od biológie k politike..., hlavne s. 299-303.

BUTLER, J. How can I deny..., s. 256. 
Radikálne konštruktivistický prístup, pre ktorý je ono zdoslovnenie trópu performativity charakteristické, vyústuje podla autorky do jazykového monizmu $^{6}$ a tým pádom vedie i $\mathrm{k}$ neschopnosti spolahlivo sa vysporiadat s matériou tela. ${ }^{7}$ Radikálne konštruktivistický prístup redukujúci kultúrne formovanie javov na číry verbálny proces vyústuje bud’ do kultúrneho determinizmu, alebo do úsilia pátrat po voluntaristickom subjekte. Kultúrny determinizmus postuluje, že človek je tým, čím je, v dôsledku pôsobenia kultúrnych vzorov. Tradičným protipólom kultúrneho determinizmu je biologický determinizmus, podla ktorého je človek daný biologickými faktormi, napr. rasou alebo pohlavím. ${ }^{8} \mathrm{~V}$ prípade voluntaristického subjektu sa deleguje konštrukcia subjektu na subjekt sám, na jeho vlastné vedomé uváženie. Butlerová v daných prístupoch identifikuje figúru aktívne pôsobiaceho subjektu, ktorý plní funkciu teleologickej inštancie v procese konštrukcie. Takýto teleologický subjekt je jedinou príčinou a súčasne ciel’om celého procesu konštrukcie. Podla Butlerovej je takéto chápanie dôsledkom aplikácie štruktúry gramatiky jazyka na kultúrne procesy. Štruktúra gramatiky totiž predpokladá na počiatku každého deja aktívne pôsobiace činitele. ${ }^{9}$ Zatial' čo v prípade hladania voluntaristického subjektu prostredníctvom otázky „kto konštruuje?“ je takáto aplikácia gramatiky očividná, v prípade kultúrneho determinizmu dochádza k personifikácii kultúry. ${ }^{10}$ Kultúra vystupuje ako niekto, kto disponuje vlastnou vôlou a mocou rozhodovat o tom, ako bude konštrukcia realizovaná.

V danom kontexte ma budú zaujímat dve otázky, ktorými sa autorka zaoberá. Po prvé, možnost̉ aktívneho pôsobenia alebo činitel'ská inštancia (agency). ${ }^{11}$

6 Pod jazykovým monizmom sa mieni vyššie uvedená predstava, že svet je jazykom formovaný nielen na epistemickej úrovni, ale sám svet má jazykovú podstatu. Mimo jazyka niet ničoho iného.

7 BUTLEROVÁ, J. Závažná těla..., s. 21-22.

8 Porovnaj napr. BENEDICT, R. Vzory kultúry..., napr. s. 186-188.

9 BUTLEROVÁ, J. Závažná těla..., s. 22-23. Žiada sa ešte dodat, že kultúrna antropologička Ruth Benedictová v práci Patterns of Culture (Vzory kultúry, 1934), na ktorú odkazujem v predchádzajúcej poznámke, upozorňuje podobne ako Judith Butlerová na zásadný vplyv jazykových konštrukcií pri uvažovaní o kultúre. Benedictová si všíma, že jazykové prostriedky, ktoré personifikujú mimo-l'udské entity, napr. umelecké smery (s. 44) či súbory záväzných tradícií určitého spoločenstva (s. 185) môžu vyvolávat̉ dojem mysticizmu. Akoby jestvovala akási vonkajšia rozumná sila, ktorá manipuluje chodom dejín a ludským správaním.

10 BUTLEROVÁ, J. Závažná těla..., s. 25. Doplňme, že obdobne ako sa v prípade kultúrneho determinizmu personifikuje kultúra, tak sa v biologickom determinizme personifikuje biológia.

11 S pojmom agency sú spojené prekladatel'ské patálie. Jana Juráňová ho v slovenskom preklade knihy Gender trouble prekladá ako schopnost' konat'. Josef Fulka sa vo svojom preklade Bodies that matter uchýlil k variabilnému kontextuálnemu riešeniu, ked' používa rozličné 
Po druhé, vztah matérie a jazyka. Obe otázky sa v autorkinej filozofii koncentrujú okolo motívu odmietnutia tela ako nepopísaného prírodného povrchu očakávajúceho kultúrny zápis. Tento motív je pritom zásadný pre autorkinu koncepciu performatívnej identity. Z týchto dôvodov, prv než sa budem zaoberat' uvedenými dvoma otázkami, bude potrebné pristavit’ sa pri autorkinej koncepcii performatívnej identity, hoci je v českom i slovenskom kontexte relatívne dobre známa. ${ }^{12}$

\section{Butlerovej koncepcia performatívnej identity}

Základnou tézou autorkinej koncepcie performatívnej identity je, že „[n]eexistuje žiadna rodová identita, ktorá by bola za prejavmi rodu; takáto identita je performatívne konštituovaná práve tými ,prejavmi‘, o ktorých tvrdí, že sú jej výsledkami“. ${ }^{13}$ Ked’že niet rodovej identity samej osebe, do ktorej by bolo možné subjekt jednoducho navliect', ale je kategóriou utváranou v prejavoch subjektu, tak nikdy nie je kategóriou definitívne zavŕšenou a celistvou. Znamená to, že „v žiadnom časovom bode nie je tým, čím je“. ${ }^{14}$ Butlerová prisudzuje dôležité miesto telesnosti. Už v Trampotách s rodom sa rod chápal ako „opakovaná štylizácia tela, súbor opakovaných aktov v rámci velmi meravého regulačného rámca, ktorý pôsobí ochromujúco, takže vytvára zdanie sub-

varianty, ako napríklad schopnost’ aktívneho pôsobenia alebo konania, činitel'ská inštancia. Obdobným spôsobom pracujem s týmto termínom aj ja.

12 Známa je najmä vd’aka prekladom (knižným i časopiseckým), rozvoju rodových štúdií a sekundárnej literatúre od tunajších autorov i autoriek, napr. BARŠA, P. Judith Butlerová...; GÓRSKA, M. - MATONOHA, J. Popis mnoha zápasů..., alebo KOBOVÁ, L. Čo je materiálne?..., s. 300-304. Známa je tak najmä medzi odbornou verejnostou. Nielen idey Judith Butlerovej, ale v širšom kontexte i základné teoretické predpoklady rodových štúdií sú v súčasnosti znova (či ešte stále?) atakované zástancami „tradičných hodnôt“. Na Slovensku možno za jednu z takýchto platforiem ataku považovat konzervatívny denník Postoj, hoci vonkoncom nejde o jediný bod agendy tohto média. Symptomatickým je z tohto hladiska článok HANUS, M. Choroba menom gender... Autor sebavedomo zosmiešňuje postuláty konštruktivizmu a vedno s tým i Judith Butlerovú. Konštruktivizmus pritom interpretuje práve z pozícií, ktoré Butlerová kritizuje. V Hanusovom článku sú vedla seba všetky vyššie uvedené stereotypy konštruktivizmu - figúra aktívne pôsobiaceho subjektu, ktorý stojí na počiatku konštrukcie, a jazykový monizmus. Autor sa následne vôbec nevie vysporiadał s tým, aký vztah panuje medzi matériou a jazykom, a preto sa mu zdá absurdné, že sa ženami či mužmi nerodíme, ale stávame. Aj tento prípad ukazuje dôležitost̉ opätovných návratov k prameňom.

13 BUTLER, J. Trampoty s rodom..., s. 66.

14 Tamže, s. 55. 
stancie, prirodzeného druhu bytia“ ${ }^{15} \mathrm{~V}$ tejto definícii je implicitne prítomná polemika s chápaním tela a tým pádom aj pohlavia ako biologickej danosti, nepoškvrneného prírodného základu. Autorka upozorňuje, že už rodová a kultúrne konštruovaná kategória „žena“ kopíruje binárny systém dvoch pohlaví. Diferencia rodu a pohlavia však vedie k diverzifikácii rodu, pretože ak je rod kultúrnou konštrukciou, niet príčiny, aby bezprostredne vyplýval z pohlavia. Tým sa pre autorku otvára priestor pre postulovanie pohlavia ako kultúrnej konštrukcie. ${ }^{16}$ Umiestňovaním pohlavia do prediskurzívnej oblasti ako nepopísaného prírodného základu očakávajúceho kultúrny zápis rodu dochádza k zakrývaniu diskurzívnej podstaty samého aktu umiestnenia. ${ }^{17}$

Pochopitel'nou otázkou je, či sa náhodou aj sama autorka nechytila do pasce zdoslovnenia trópu performativity a jazykového monizmu. Znamenalo by to, že ani ona by nebola schopná poradit si vo svojich analýzach s telom a jeho materialitou, pretože by sa javila iba ako výsledok verbálneho procesu. Za presvedčivý dôkaz, že tomu tak nie je, považujem najmä fakt, že v autorkinej koncepcii dochádza ku konštrukcii nielen rodu, ale i pohlavia zvnútornenými vonkajšími telesnými aktmi. Ide o figúru vnútrajškovosti, ktorou Butlerová vysvetluje, ako sa vonkajšie telesné akty, vrátane túžby, presúvajú do vnútra subjektu, v dôsledku čoho sa naturalizuje proces konštrukcie. ${ }^{18} \mathrm{~V}$ súvislosti s "prevzatím“ pohlavia filozofka píše, že sú tieto vonkajšie telesné akty mobilizované regulačným aparátom heterosexuálnej matrice, ktorý zohráva úlohu zákona. Ide tak o zákon, ktorý k činnosti vyzýva, no túto činnost' nedeterminuje. V nadväznosti na Derridovo chápanie performativity ako citovatel'nosti ${ }^{19}$ Butlerová navrhuje o týchto vonkajších telesných aktoch „preberajúcich“ pohlavie hovorit’ ako o citáciách onoho mobilizujúceho zákona, ktorý by bez citácií ani zákonom nemohol byt. To znamená, že zákon nejestvuje pred vlastnou citáciou, ale produkuje sa vd’aka nej. ${ }^{20} \mathrm{~V}$ autorkinej

15 Tamže, s. 75.

16 Tamže, s. 43-44.

17 BUTLEROVÁ, J. Závažná těla..., s. 20.

18 BUTLER, J. Trampoty s rodom..., s. 210-218.

19 Ide o Derridovu ideu, ku ktorej dospel pri dekonštrukcii teórie performatívu J. L. Austina (k Austinovej teórii vid’ poznámku 41). Citovatel'nost’ zjednodušene znamená, že každá výpoved', aby bola rozpoznatelná a pochopitelná, musí byt’ opakovatel'ná, a teda oplývat možnostou byt citovaná a oddelitel'ná od kontextu, v ktorom sa pôvodne vyskytla. Vid' DERRIDA, J. Texty $k$ dekonstrukci..., najmä s. 291-292. Porovnaj tiež MATONOHA, J. A KOL. $\mathrm{Za}$ (de)konstruktivismem..., s. 135-138. 
koncepcii sú tým pádom rod i pohlavie akýmisi fiktívnymi originálmi, okolo ktorých sa reiteráciou vonkajších telesných aktov usádzajú kultúrne sedimenty, metalepticky ${ }^{21}$ vytvárajúce efekt prirodzenosti.

\section{Rozklad opozície subjekt/objekt rozkladom exkluzivity činitel'skej inštancie}

Opísaná autorkina koncepcia vrhá viac svetla na jej kritické chápanie kultúrneho determinizmu. Znamená pre ňu predstavu akéhosi prvotného hýbatela, ktorý disponuje neobmedzenou schopnostou konania a ktorý s konečnou platnostou určuje podstatu nejakej entity. Z týchto príčin odmieta i predstavu o voluntaristickom subjekte. Ten podobne rozhoduje sám o sebe. V oboch prípadoch sa konfrontujeme s figúrou Boha, ktorý entity pomenováva, a tým i vytvára („božský performatív“). ${ }^{22}$ Dalo by sa povedat’, že konštruktivizmus môže v radikálnych prípadoch vyústit do kreacionizmu. Týmto sa otvára možnost̉ reflektovat prvý z dvoch v úvode naznačených problémov. Ide o problém činitel’skej inštancie či schopnosti aktívneho pôsobenia. Koncepcia Butlerovej prekonáva predstavu, že na počiatku konštrukcie musí byt’ výlučne jeden faktor.

V záverečnej kapitole Trampôt s rodom vyjadruje filozofka presvedčenie, že jej koncepcia podrýva epistemologickú dichotómiu subjektu a objektu. ${ }^{23}$ Uvažovanie nemusí mat' iba tento vektor. Subjekt nemusí bezvýhradne vládnut̉ nad objektom a nemusia voči sebe nezmieritel'ne stát. Rozklad voluntaristického subjektu svojvolne utvárajúceho vlastnú identitu ako svoj objekt v autorkinom myslení sprevádza rozklad personifikácie kultúrneho determinizmu, a teda objektovej pozície kultúrou konštruovaného subjektu.

K rozkladu týchto koncepcií autorka dospieva tým, že chápe identitu ako prax označovania prostredníctvom vonkajších telesných aktov. Táto prax síce

21 Metalepsia spočíva v zámene príčiny a dôsledku. V tomto prípade to znamená, že to, čo sa javí byt pôvodom, je v skutočnosti iba efektom. Dôležitým je pritom najmä moment naturalizácie efektu ako pôvodu. Vid’ MATONOHA, J. Pasti performativity..., s. 26-27. Derrida na túto metalepsiu zrozumitelne poukázal vo svojej analýze subjektu americkej Deklarácie nezávislosti, retroaktívne konštruujúcej lud, v mene ktorého nezávislost’ deklaruje. Vid' DERRIDA, J. Declaration of Independence...

22 Porovnaj BUTLEROVÁ, J. Závažná těla..., s. 22, 31, 280. Butlerová sa tu dotýka problematiky rečových aktov, o ktorej pôjde reč v záverečnej časti štúdie.

23 BUTLER, J. Trampoty s rodom..., s. 225-234 a tu najmä s. 228-229. 
má regulatívne pravidlá založené na iterabilite, no, ako som už uviedol, nejde o pravidlá determinujúce, ale stimulujúce:

[O]značovanie nie je zakladajúcim aktom, ale skôr regulovaným procesom opakovania, skrývajúcim a presadzujúcim svoje pravidlá vytváraním dojmu substancializácie. Označovanie sa deje v režime vynúteného opakovania, avšak pravidlá riadiace označovania nemusia iba obmedzovat', ale umožňujú tiež nastolovat nové možnosti.... ${ }^{24}$

To znamená, že subjekt si síce nemôže zvolit, či bude pravidlá opakovat, môže si však zvolit, ako bude opakovanie vyzerat', čím sa pravidlá stávajú transformovatel'nými.

V eseji Conscience Doth Make Subjects of Us All (Svedomie z nás všetkých robi subjekty, 1997) interpretuje Butlerová Althusserovu teóriu interpelácie. Základnou tézou tejto Althusserovej teórie je, že „ideológia interpeluje jedincov ako subjekty“. Táto téza vychádza z predpokladu, že subjekt i ideológia sú pre seba vzájomne konštitutívne. Althusser v danej súvislosti uvádza alegorickú (za takú ju považuje Butlerová) situáciu, kedy na ulici policajt zakričí „Hej, ty“ a jedinec sa otočí, lebo rozpozná, že ide o neho. Podobnú interpelačnú situáciu Althusser vidí aj v súvislosti s nenarodeným dietatom, ktoré ešte pred tým, než príde na svet, už má meno a priezvisko a po narodení bude zastávat́ nenahraditel'né miesto, a tak sa $\mathrm{z}$ neho stáva subjekt. ${ }^{25}$

Butlerová premýšla o oslovení ako o túžbe podriadit sa zákonu (reprezentovanému napr. policajtom) bezprostredným prijatím viny. Otočenie sa na oslovenie je podla autorky akt podmienený jednak zákonom a jednak reakčnou schopnostou osloveného, pričom ani zákon a ani oslovený nemajú nad otočením absolútnu moc:

K žiadnemu otočeniu by síce nedošlo bez toho, aby bol človek najskôr oslovený, ale nedošlo by $\mathrm{k}$ nemu ani vtedy, keby človek nebol do istej miery pripravený otočit sa. ${ }^{26}$

24 Tamže, s. 230.

25 Vid' ALTHUSSER, L. On ideology..., s. 44-51. Podrobnejšie než moja štúdia sa problematike interpelovaniu subjektu venovala napríklad POPA, D. Oslovený subjekt...

26 BUTLER, J. Svědomí z nás..., s. 238. 
Autorku na tom zaujíma najmä to, ako je možné, že je človek nútený otočit sa na volanie zákona skôr, než má možnost' kriticky ho zhodnotit. Prvotnou podmienkou subjektivácie sa tak javí byt jedincovo stotožnenie s niekým, kto porušil zákon. To znamená, že vina predchádza zákon, čo autorka označuje za „afektívnu spätost' so zákonom“. ${ }^{27}$ Autorka sa v tejto eseji podrobne zaoberá tým, ako je u Althussera človek podmaňovaný zákonom prostredníctvom nadobúdania virtuozity jeho ovládania a reprodukcie. ${ }^{28} \mathrm{Na}$ tomto mieste je však dôležité to, ako sa Butlerová v závere vracia k afektívnemu putu medzi subjektom a zákonom a identifikuje v ňom predpoklady, umožňujúce subjektu kritiku zákona. Ked’že zákon zaručuje „bytie“ subjektu, aby mohlo dôjsț ku kritike zákona, subjekt musí oplývat istou vôlou „nebyt“, čím by sa monopol „bytia“ v rukách zákona ukázal slabší, než sa javí. Otvorila by sa tak cesta pre iné cesty „bytia“ a bolo by možné skúmat, ako zákon a zákony rôzneho druhu využívajú vôlu subjektu k „bytiu“ na jeho podmanenie. ${ }^{29}$

Miera schopnosti aktívneho konania, ktorú autorka subjektu prisudzuje, má dôsledky aj v politickej rovine. Fiktívnu originalitu pohlavia a rodu, a v podstate aj subjektu, ako bol opísaný v predchádzajúcom odstavci, prepája Butlerová s úvahami Slavoja Žižeka o politických označujúcich a fantazmatických obsadeniach. Politické označujúce sú slová ako lavica, sociálni demokrati, študenti, ženy a pod. Vymedzujú určité subjektové pozície, no nereprezentujú čosi vopred jestvujúce. Sú prázdnymi znakmi, čím sa stávajú nositel'mi rôznorodých fantazmatických obsadení. To znamená, že rôzne skupiny ludí s vidinou vymedzenia vlastnej pozície ako politických subjektov môžu politické označujúce napĺn̆at rôznym obsahom. Obsadenie politického označujúceho je fantazmatickým preto, lebo vyvoláva očakávania jednoty, ktorú však nikdy nemožno definitívne dosiahnut. S odvolaním sa na teóriu radikálnej demokracie Ernesta Laclaua a Chantal Mouffovej vidí Butlerová v onom neustálom zlyhávaní dosiahnutia jednoty významný potenciál pri reartikulácii politických označujúcich, čo je základom boja za vlastné práva rôznych skupín. ${ }^{30}$

27 Tamže.

28 Tamže, s. 244-246.

29 Tamže, s. 253.

30 BUTLEROVÁ, J. Závažná těla..., s. 254-256. 


\section{Materialita ako prepojenie matérie a jazyka}

Predchádzajúca čast’ okrem iného poukázala na to, ako rôzne telesné akty subjektu pôsobia aktivizujúco voči kultúrnym sedimentom, zoskupujúcim sa okolo týchto aktov v dôsledku neustálej reiterácie. Znamená to, že telo nie je subjektu prístupné ako biologická danost', ale vždy už ako kultúrne či diskurzívne opracované. Signifikantná je nasledujúca pasáž z autorkinej knihy Bodies That Matter (Závažné telá, 1993):

Tělo kladené jako něco, co předchází znaku, je vždy kladeno či vyznačováno jako předchůdné. Toto značení coby účinek svého vlastního postupu vytváří právě ono tělo, o němž však zároveň prohlašuje, že je odhaluje jako to, co jeho vlastnímu působení předcházi. Jestliže tělo, vyznačované jako to, co předchází významu, je ve skutečnosti jeho účinkem, potom jazyk, jehož mimetický či reprezentační status je postavený na tvrzení, že znaky následují až po tělech jako jejich nutné odrazy, nikterak mimetický není. Právě naopak, je produktivní, konstitutivní, dalo by se dokonce říci performatiuni $\mathrm{v}$ té míře, $\mathrm{v}$ jaké tento akt značení vymezuje a vytyčuje obrysy těla, o němž potom tvrdí, že je nalézá před veškerým významem. ${ }^{31}$

Autorkina koncepcia teda podrýva reprezentatívnu funkciu jazyku, podla ktorej je jazyk odrazom matérie sveta. Gilles Deleuze a Felix Guattari v spise Mille plateaux (Tisíc plošín, 1980) uvažujú obdobne, ked' označujú výpoved' za rozkaz určujúci pravidlá používania jazyka, a reč je tak množinou takýchto rozkazov. Poukazujú na to, že reč nefunguje na princípe označovania a reprezentácie videného v materiálnom svete, ale naopak na princípe neustáleho sprostredkovávania započutých rozkazov, ktoré neinformujú o stave materiálneho sveta, no utvárajú našu predstavu o ňom. ${ }^{32}$ Vzṫah matérie a jazyka sa tak ukazuje byt komplikovanejším a neredukuje sa na zrkadlenie, čo je zásadné pre pojatie materiality u Butlerovej. Autorka o nej premýšla ako o prepletení matérie a jazyka. $\mathrm{V}$ danej chvíli sa tak dostávame $\mathrm{k}$ druhému problému naznačenému v úvode.

Filozofka skúmanie toho, čo je to materialita, začína pri etymológii latinského materia a starogréckeho hylé. Upozorňuje, že materia je nielen materiálom pre výrobu d’alších vecí, ale označuje aj potravu pre deti a hylé zasa označuje drevo zo stromu pripravené pre d’alšiu výrobu. Znamená to, že

31 Tamže, s. 53.

32 DELEUZE, G. - GUATTARI, F. Tisíc plošin..., s. 91. 
látka má schopnost’ stát na počiatku niečoho. Okrem materiálnej základne preto disponuje aj princípom inteligibility, čo znamená, že je táto materiálna základňa rozumovo uchopitel'ná, s cielom byt d’alej spracovaná. ${ }^{33} \mathrm{~V}$ danej súvislosti pripomína Aristotelovo pojatie duše ako aktualizácie látky, čo znamená, že látka (hylé) sa nikdy nejaví bez svojho tvaru (schéma). Butlerová tým chce povedat, že predmety sa javia v určitom „gramatickom“ tvare a že princíp ich rozpoznatel’nosti tak nemožno oddelit od ich materiálnej podstaty. ${ }^{34}$ Implicitné prepracovanie tohto Aristotelovho princípu neoddelitelnosti látky od tvaru vidí autorka vo Foucaultových úvahách o duši, moci a tele. Pripomína, že u Foucaulta duša zastáva pozíciu nástroja moci kultivujúceho telá. Duša je normatívnym a normalizujúcim ideálom, ku ktorému telo pri svojom utváraní vzhliada. Takto chápaná duša je teda tvarom aktualizujúcim látku. ${ }^{35}$ Proces materializácie tela u Foucaulta v autorkinej interpretácií prebieha ako účinok moci. Moc však nie je vonkajšou silou. Autorka tu znova aktualizuje figúru vnútrajškovosti. ${ }^{36}$

Pre autorkino pojatie materiality sú teda dôležité mocenské aspekty vztahu matérie a jazyka. V nasledujúcich odstavcoch sa však chcem pristavit primárne pri semiotickej rovine tohto vztahu, ktorou sa Butlerová zaoberá na niekol'kých stranách v Závažných telách. ${ }^{37} \mathrm{Na}$ týchto stranách je dobre vidiet autorkino chápanie prepojenia matérie a jazyka.

Autorka operuje s pojmami označujúce, označované a referent, ktoré však explicitne nedefinuje. Vystríha však pred stotožňovaním označovaného s referentom, pretože referent podla nej nikdy nie je v označovanom natrvalo a úplne obsiahnutý. Referent autorka nazýva jazykom nezachytitelnou absenciou. Takáto unikajúca povaha referentu vedie $\mathrm{k}$ tomu, že sa jazyk znova a znova usiluje o jeho zachytenie. Vo svojom úsilí však neustále zlyháva. Referent teda akoby v jazyku súčasne bol i nebol.

Príčinou zlyhania jazykovej fixácie referentu je odlišný ontologický status matérie a jazyka. Ako však už vieme, Butlerová sa usiluje prekonat dichotómiu medzi jazykom a matériou. Odlišný ontologický status jazyka a matérie tak neznamená, že ich nič nespája, alebo naopak, že jazyk pohlcuje matériu,

\footnotetext{
33 BUTLEROVÁ, J. Závažná těla..., s. 54-56.

34 Tamže, s. 57.

35 Tamže, s. 58.

36 Túto figúru, mimochodom, autorka rozpracovala v priamej nadväznosti na Foucaultovo pojatie subjektivácie ako subjekcie. Porovnaj napr. FOUCAULT, M. Prečo študovat moc...

37 BUTLEROVÁ, J. Závažná těla..., s. 100-102.
} 
a tým pádom niet ničoho mimo jazyka. Ako sme videli už vyššie, autorka sa voči takejto koncepcii vymedzuje. Zároveň však filozofka predsa len ukazuje nemožnost’ vykročit do materiálneho priestoru, ktorý by stál mimo jazyk, pretože už sama jazyková referencia oplýva materiálnou povahou. Znova pripomínam, že nejde o popretie existencie matérie ako takej. Ide o to, čo sa s matériou stane, ak o nej začneme hovorit. Neznamená to, že by sa matéria začala pod tarchou hovorenia menit vo svojej materiálnosti. Skôr máme dočinenia s čímsi ako netelesnou transformáciou v pojatí Deleuza a Guattariho. Deleuze s Guattarim o netelesných transformáciách píšu ako o aktoch pripísania telám atribútov netelesnej povahy, napr. rozhodnutím súdu sa obvinený mení na odsúdeného, hoci jeho telo zostáva tým istým. Osobitostou takýchto transformácií je, že samé osebe sú netelesné, no vo vztahu k telám sú vnútorné. ${ }^{38}$ Hoci sú teda netelesné, tiel sa bytostne týkajú. Obdobne pristupuje Butlerová k problému jazykového uchopenia matérie. Znaky sa vyjavujú za pomoci materiálnych prostriedkov, napr. vizuálnych alebo zvukových. Aby mohla matéria nadobudnút význam, musí byt kontaminovaná jazykom, a naopak jazyk sa pri označovaní spolieha na materiálne prostriedky.

Záverom tejto autorkinej úvahy je, že označujúce a označované sú súčasne späté i oddelené a to prostredníctvom vzájomnej materiálno-jazykovej kontaminácie. Obdobný vztah panuje aj medzi označovaným a referentom, kde dochádza k stretu svetov matérie a jazyka. Matéria a jazyk sú chiazmaticky prepletené, jedno v druhom vzájomne ukotvené a jedno na druhé neredukovatelné, čo bol zároveň jeden z autorkiných postulátov, ktoré som uviedol hned' na začiatku.

Teraz bude namieste bližšie sa pristavit pri pojmoch označujúce, označované a referent, ktoré Butlerová užíva. Využijem k tomu dyadický model znaku Ferdinanda de Saussura. V tomto modeli je znak tvorený označujúcim a označovaným, pričom označujúce je akustickým obrazom prítomným v ludskej mysli a označované je pojmom. Jedno druhé pritom recipročne vyvoláva. ${ }^{39}$ De Saussurovo pojatie znaku teda nevychádza z predstavy, že existuje označujúce meno, ktoré je ideálnou reprezentáciou označovaného materiálneho objektu. De Saussure sa pohybuje v oblasti jazyka, čo je zrejmé už z toho, že hovorí o jazykovom znaku a nie o znaku ako takom. Vyššie som uviedol, že Butlerová odmieta stotožnenie označovaného s referentom. Zo saussurovskej perspektívy (v ktorej síce referent ako tretí člen modelu znaku

38 DELEUZE, G. - GUATTARI, F. Tisíc plošin..., s. 95-97.

39 SAUSSURE, F. de. Kurs obecné lingristiky..., s. 95-97. 
absentuje) sa dá na jednej strane konštatovat, že referent nie je ani pojem, a na druhej strane, že referent nie je ani materiálny objekt. ${ }^{40}$ Preto o referente autorka píše ako o jazykom nezachytitel'nej absencii, ako o niečom, čo v jazyku súčasne je i nie je. Ak by referent bol pojmom, znamenalo by to, že niet ničoho mimo jazyka. Ak by bol naopak materiálnym objektom, znamenalo by to utvrdenie dichotómie medzi jazykom a matériou (a spolu s tým i reprezentatívnej funkcie jazyka), ktorú sa autorka usiluje zneistit.

Pri snahe lepšie pochopit autorkinu koncepciu materiality môže byt’ prínosné obrátit sa k problematike rečových aktov. Francúzska filozofka Shoshana Felmanová dospieva pri analýze teórie rečových aktov J. L. Austina ${ }^{41}$ k podobným záverom ako Butlerová vo vyššie opísaných úvahách. Felmanová sa domnieva, že Austin prinavrátil do lingvistického diskurzu referent. Podla autorky nie je pre Austina referent prediskurzívnou veličinou reprezentovanou v jazyku, ale objavuje sa ako výsledok pôsobenia jazyka. ${ }^{42}$ Rečový akt je z tohto hladiska autoreferenčným, pretože produkuje sám seba ako svoj vlastný referent. ${ }^{43}$ Jazyk tak má podl’a Felmanovej schopnosṫ presiahnut sám seba, aktívne vstúpit do materiálneho sveta a modifikovat ho. Nazýva to referenčným presahom výpovede. ${ }^{44}$ Austinova teória podla Felmanovej predstavuje nový typ materializmu, založený na interakcii matérie a jazyka. Vysvetluje to pomocou fyzikálnej koncepcie hmoty, ktorá nejestvuje sama osebe. Hmota je súbor prvkov spojených pôsobením energie. Felmanová pristupuje k tejto fyzikálnej koncepcii hmoty ako k figúre. Hmotu následne prirovnáva k rečovému aktu. V rečovom akte matéria jazyka (frázy, fragmenty viet, označujú-

$40 \mathrm{~K}$ problematike referenta ako materiálneho (mimo-jazykového) objektu vid' napr. OGDEN, C. K. - RICHARDS, I. A. Myšlenky, slova a věci...

41 Austinova teória je spočiatku založená na rozlíšení výpovedí na konštatívne a performatívne. Zatial' čo pri konštatívoch sa dá overit’ ich pravdivost', performatívy sú aktmi prostredníctvom jazyka, napr. slub alebo ospravedlnenie, ktoré môžu byt bud' vydarené alebo nevydarené. Austin však túto počiatočnú opozíciu vo svojej práci postupne cielavedome rozkladá a dospieva k tomu, že aj konštatívy sú svojho druhu performatívy. K zblíženiu spočiatku nezlučitelných foriem výpovedí dochádza prostredníctvom pojmu ilokučnej sily alebo účinku, ktorý výpoved' vyvoláva. Rozdiel medzi konštatívom a performatívom tak spočíva v miere tejto sily (AUSTIN, J. L. Ako niečo robit’ slovami...). Porovnaj môj stručný výklad s BERTA, J. Rečové akty z aspektu filozoficko-lingvistického..., s. 552-557, alebo s MARVAN, T. Otázka význaтu..., s. 165-170.

42 FELMAN, Sh. The Scandal of The Speaking Body..., s. 51.

43 Tento pohlad na referent vrhá inú perspektívu na autoreferenčnoste rečových aktov, než je koncepcia Émila Benvenista, založená na predpoklade apriórne prítomnej štruktúry subjektivity v jazyku. Vid' BENVENISTE, É. Obščaja lingvistika..., s. 293-297.

44 FELMAN, Sh. The Scandal of The Speaking Body..., s. 53-54. 
ce) plní funkciu prvkov a ilokučná sila zasa funkciu energie. Rečový akt sa potom javí ako oblast' nerozhodnutel'ného recipročného pôsobenia matérie a jazyka. ${ }^{45}$

Obdobne o rečovom akte uvažovali i Deleuze s Guattarim, ked' naň nahliadali ako na oblast’ stretu jazyka so sférou sociálna, ${ }^{46}$ čím artikulovali implicitný eticko-politický osteň teórie rečových aktov. Sú to práve eticko-politické aspekty procesu konštrukcie, ktoré primäli Judith Butlerovú prehodnotit pojatie materiality. Filozofku zaujímajú mechanizmy konštrukcie. Tie sú nemyslitel’né bez regulačných rámcov diskurzu a inštitúcií, no súčasne nie sú myslitel'né bez aktívne pôsobiacich tiel. Vyššie som ukázal, že Butlerová činitel'skú inštanciu konštrukcie pluralizuje. Hoci subjekt nemá možnost̉ vyhnút sa svojej konštrukcii regulovanej diskurzom a inštitúciami, môže aktívne participovat na tom, ako konštrukcia prebieha. Eticko-politické otázky sa vynárajú vtedy, ak si uvedomíme, že regulačný aparát diskurzu a inštitúcií síce napomáha k rozpoznaniu subjektov, avšak zároveň niektoré subjekty z rozpoznania vylučuje. Naliehavým sa potom stávajú otázky o tom, ako zaručit rozpoznanie aj menej „vyhovujúcim“ subjektom. ${ }^{47}$ Hoci som v predchádzajúcich odstavcoch interpretoval prístup k vztahu matérie a jazyku u Butlerovej cez prizmu „neutrálnej“ problematiky teórie znaku, eticko-politickej nástojčivosti tohto vztahu sa vyhnút nemožno. Je tomu preto, že autorka kladie do centra pozornosti telo, ktorého vonkajšie prejavy sú nevyhnutnou praxou vlastného označovania. Takto sa Butlerovej darí preklenút dichotómiu matérie a tela, spolu s ňou pojatie jazyka ako reprezentácie matérie a postulovat znak ako recipročnú kontamináciu matérie a jazyka.

\section{Zoznam použitých zdrojov}

ALTHUSSER, Louis. On ideology. London - New York: Verso 2008.

AURELIUS, Eva Haettner - CHENGZHOU, He - HELGASON, Jon. Performativity in Literature: The Lund - Nanjing Seminars. In AURELIUS, Eva Haettner - CHENGZHOU, He - HELGASON, Jon (eds.). Performativity in Literature. Stockholm: KVHAA 2016, s. 9-26.

AUSTIN, John Langshaw. Ako niečo robit’ slovami. Preložil Dezider KAMHAL. Bratislava: Kalligram 2004.

45 Tamže, s. 108-109.

46 DELEUZE, G. - GUATTARI, F. Tisic plošin..., s. 92.

47 Vid' FULKA, J. Od konstrukce k etice..., s. 330-331. 
BARŠA, Pavel. Judith Butlerová: teorie performativního rodu a dilemata současného feminismu. Filosofický časopis 1999, 47(5), s. 772-785.

BENEDICT, Ruth. Vzory kultúry. Preložila Marianna DACHOVÁ. Bratislava: Kalligram 1999.

BENVENISTE, Émile. Obščaja lingvistika. Preložila Ju. N. KARAULOVOVÁ a kol. Moskva: Progress 1974.

BERTA, Jozef. Rečové akty z aspektu filozoficko-lingvistického. Filozofia 2005, 60(8), S. $551-572$.

BUTLER, Judith. How Can I Deny That These Hands And This Body Are Mine? In COHEN, Tom - COHEN, Barbara - MILLER, Joseph Hillis - WARMINSKI, Andrzej (eds.). Material Events. Paul de Man And The Afterlife of Theory. Minneapolis - London: University of Minnesota Press 2001, s. 254-274.

BUTLER, Judith. Svědomí z nás všech činí subjekty. Filosofický časopis 2013, 61(2), s. 237-256.

BUTLER, Judith. Trampoty s rodom: Feminizmus a podrývanie identity. Preložila Jana JURÁŇOVÁ. Bratislava: Aspekt 22014.

BUTLER, Judith. Závažná těla: O materialitě a diskursivnich mezich „pohlavi“. Preložil Josef FULKA. Praha: Karolinum 2016.

DELEUZE, Gilles - GUATTARI, Felix. Tisíc plošin. Preložila Marie CARUCCIO CAPORALE. Praha: Herrmann a synové 2010.

DERRIDA, Jacques. Declaration of Independence. Preložili Tom KEENAN a Tom PEPPER. New Political Science 1986, 7(1), s. 7-15.

DERRIDA, Jacques. Texty $k$ dekonstrukci: práce z let 1967-1972. Preložil Miroslav PETř́́ČEK. Bratislava: Archa 1993.

FELMAN, Shoshana. The Scandal of The Speaking Body: Don Juan with J. L. Austin, or Seduction in Two Languages. Preložila Catherine PORTER. Stanford: Stanford University Press 2003.

FOUCAULT, Michel. Prečo študovat moc: otázka subjektu. Preložil Miroslav MARCELLI. In GÁL, Egon - MARCELLI, Miroslav (eds.). Za zrkadlom moderny. Bratislava: Archa 1991, s. 42-52.

FULKA, Josef. Od konstrukce k etice: Závažná těla a jejich kontext. In BUTLEROVÁ, Judith. Závažná těla: O materialitě a diskursivnich mezich „pohlavi“. Praha: Karolinum 2016, s. 317-338.

GÓRSKA, Magdalena - MATONOHA, Jan. Popis mnoha zápasů: diskurz, subjekt a moc v myšlení Judith Butlerové. Česká literatura 2008, 56(6), s. 805-829.

HANUS, Martin. Choroba menom gender. Postoj, 23. 10. 2018 [online, cit. 19. 2. 2019]. Dostupné z: 〈https://www.postoj.sk/37419/choroba-menom-gender〉.

LOXLEY, James. Performativity. London - New York: Routledge 2007.

KOBOVÁ, Lubica. Čo je materiálne? Rod, sexuálna diferencia a sexualita v materialistických feminizmoch. In HECZKOVÁ, Libuše a kol. Vztahy, jazyky, těla: Texty z 1. konference českých a slovenských feministických studii. Praha: ERMAT 2007, s. 298-312.

KRIŠTOFOVÁ, Lenka. Sexualita: Od biológie k politike, slasti a slobode. In KICZKOVÁ, Zuzana - SZAPUOVÁ, Mariana (eds.). Rodové štúdiá: Súčasné diskusie, problémy a perspektívy. Bratislava: Univerzita Komenského v Bratislave 2011, s. 294-311

MARVAN, Tomáš. Otázky významu: Cesty analytické filosofie jazyka. Edice SCHOLIA. Praha: Togga 2010. 
MATONOHA, Jan. Pasti performativity: dělat, jako by se nic nedělo. In SLÁDEK, Ondřej (ed.). Performance - performativita. Praha: Ústav pro českou literaturu 2010, s. 21-34.

MATONOHA, Jan a kol. Za (de)konstruktivismem: Kritické koncepty (post)poststrukturální literárni a kulturni teorie. Praha: Academia 2017.

MILLER, Joseph Hillis. Performativity ${ }_{1} /$ Performativity $_{2}$. In SAETRE, Lars - LOMBARDO, Patrizia - GULLESTAD, Anders M. (eds.). Exploring Textual Action. Aarhus: Aarhus University Press 2010, s. 31-58.

OGDEN, Charles Kay - RICHARDS, Ivor Armstrong. Myšlenky, slova a věci. Preložil Bohumil PALEK. In PALEK, Bohumil (ed.). Sémiotika: Ch. S. Peirce, C. K. Ogden E I. A. Richards, Ch. W. Morris, H. B. Curry. Praha: Karolinum 1997, s. 173-195.

POPA, Delia. Oslovený subjekt. Preložil Andrej ZÁTHURECKÝ. Filozofia 2017, 72(10), s. 769-778.

SAUSSURE, Ferdinand de. Kurs obecné lingvistiky. Preložil František ČERMÁK. Praha: Academia ${ }^{3} 2007$.

\section{Mgr. Jakub Kapičiak}

Ústav východoevropských studií, Filozofická fakulta, Univerzita Karlova nám. Jana Palacha 2, 11638 Praha 1, Česká republika

kap.jakub@gmail.com

+421904965046 
